\begin{tabular}{|l|l|l|}
\hline \multicolumn{2}{|c|}{ PublisherInfo } \\
\hline \hline PublisherName & $:$ & BioMed Central \\
\hline \hline PublisherLocation & $:$ & London \\
\hline \hline PublisherImprintName & $:$ & BioMed Central \\
\hline \hline
\end{tabular}

\title{
Let your fingers do the walking
}

\begin{tabular}{|l|c|l||}
\hline \multicolumn{2}{|c|}{ ArticleInfo } \\
\hline \hline ArticleID & $:$ & 4702 \\
\hline \hline ArticleDOI & $:$ & $10.1186 /$ gb-spotlight-20030218-01 \\
\hline \hline ArticleCitationID & $:$ & spotlight-20030218-01 \\
\hline \hline ArticleSequenceNumber & $:$ & 54 \\
\hline \hline ArticleCategory & $:$ & Research news \\
\hline ArticleFirstPage & $:$ & 1 \\
\hline \hline ArticleLastPage & $:$ & 2 \\
\hline \hline & & RegistrationDate : 2003-2-18 \\
\hline ArticleHistory & $:$ & OnlineDate \\
\hline \hline ArticleCopyright & $:$ & BioMed Central Ltd2003-2-18 \\
\hline \hline ArticleGrants & $:$ & \\
\hline \hline ArticleContext & $:$ & 130594411 \\
\hline \hline
\end{tabular}




\section{Jonathan B Weitzman}

Email: jonathanweitzman@hotmail.com

Transcription factors are often modular in nature, containing sequence-specific DNA-binding domains and transactivation domains. In an Advanced Online Publication in Nature Biotechnology Kwang-Hee Bae and colleagues at ToolGen Inc in South Korea, report the generation of "designer transcription factors" with specific binding activities (Nature Biotechnology, 18 February 2003, doi:10.1038/nbt796). A modified one-hybrid screen in yeast selected zinc-finger motifs with specific DNA-binding properties. The system was used to screen a library of over 2,000 factors that were derived from the Zif268 transcription factor and contained variant zinc-finger sequences isolated from the human genome; 56 zinc fingers with distinct DNA-binding specificities were isolated. Bae et al. shuffled the selected zinc-finger domains and tested them as transcription factors. They found that the 'natural' human zinc-finger domains function better than 'artificial' engineered zinc fingers. The designer factors could also regulate expression of a chosen endogenous genomic locus.

\section{References}

1. Nature Biotechnology, [http://www.nature.com/naturebiotechnology]

2. ToolGen Inc., [http://www.toolgen.com]

3. Zinc finger proteins as designer transcription factors.

4. Selection of peptides that functionally replace a zinc finger in the Sp1 transcription factor by using a yeast combinatorial library. 